\title{
METABOLIC STUDIES ON A CASE OF DIABETES INSIPIDUS *
}

\author{
I. M. RABINOWITCH, M.D. \\ MONTREAL, CANADA
}

Diabetes insipidus has been defined as a "chronic affection characterized by the passage of large quantities of normal urine of low specific gravity." 1

The condition has been recognized for a long time, and the literature on the subject is large. Little, however, is found which bears on its study by the newer laboratory methods. Pathologists have furnished little gross or microscopic evidence as to the nature of this affection, except in those cases of the so-called "symptomatic type" in which an organic lesion in the brain has been found as a possible cause.

Experimentally, the possibility of a central origin for the condition has been suggested. Thus it has long been known that puncture of the floor of the fourth ventricle may produce a polyuria. No definite center for the control of polyuria, however, has been found.

Disturbances in the ductless glands have been suggested as the cause of this disease. These suggestions are based on the results obtained after the injection of extracts of the various glands. The evidence obtained is conflicting. The injection of pituitary extract has been shown to produce a polyuria, and cases in which a polyuria existed have been shown to improve after the administration of pituitary extract. $^{2}$ Although many experiments associate the pituitary body with a polyuria, such a specific action of this gland has been questioned. It has been shown ${ }^{3}$ that a polyuria may be produced by a superficial lesion of the base of the brain, and this polyuria is greater than could be obtained after the injection of urea, caffein or sodium chlorid. A region has been localized (optopeduncular space) which seems to play some part in the mechanism of the regulation of water retention, with or without a polydipsia.

In 1914, Fitz, ${ }^{4}$ in a review of the subject and the report of a case, summarizes the theories held as to the nature of diabetes insipidus as

* From the Department of Metabolism of the Montreal General Hospital.

1. Osler: Principles and Practice of Medicine, Ed. 8, p. 439.

2. Christie, C. D., and Stewart, G. N.: Study of a Case of Diabetes Insipidus, with Special References to the Mechanism of Diuresis and the Action of Pituitary Extract on It, Arch. Int. Med. 20:10 (July) 1917. Schnabel, T. G., and Gerhard, A. H.: A Case of Diabetes Insipidus, New York M. J. 111:812, 1920.

3. Camus, J., and Roussy, G.: Experimental Researches on the Pituitary Body, Endocrinology 4:507, 1920.

4. Fitz, R.: Diabetes Insipidus, Arch. Int. Med. 14:706 (Nov.) 1914. 
follows: (a) That it is due to the inability of the kidney to excrete a urine of normal concentration; (b) that it is due to hyperfunction of the pituitary gland with a resultant diuretic action; (c) that it is due to a primary polydipsia with a resultant polyuria.

In the case reported by Fitz, the kidney function was found to be normal, except that it gave characteristic findings of a "vascular hyposthenuria, with the vessels sensitive to chlorid stimulation."

More recently, emphasis has been placed on the tissues of the body as a factor in the production of polyuria. As a result of certain chemicophysical changes, osmotic pressure, etc., the tissues of certain organs are unable to retain their full quota of water, and polyuria results.

In another theory an endeavor has been made to correlate a central origin with a renal factor, ${ }^{5}$ and on this basis diabetes insipidus is regarded as a disease produced by the insufficiency or lack of internal secretion of the pars intermedia of the hypophysis, a secretion which normally regulates diuresis, by acting on the renal cells, causing vasodilatation of the arteries of the kidney.

The interesting problems involved, the numerous clinical methods now available for their study and the uncommon occurrence of diabetes insipidus in this hospital (the present case being the only one recorded in the last 50,000 admissions to the wards) have stimulated the metabolic study of the following case.

\section{REPORT OF CASE}

A male (Hospital No. 666-21), aged 47, was admitted Feb. 17, 1921, to the medical wards of the Montreal General Hospital, service of Dr. H. A. Lafleur, who made the clinical diagnosis. The patient complained of a craving for water and frequency of micturition.

Personal History.-Canadian farmer, married; no previous illness, except a radical mastoid operation in July, 1920, with, apparently complete recovery. Denies venereal disease.

Family History--Irrelevant; no suggestion of syphilis.

Present Illness.-Apparently well until January, 1921, when he first noticed frequency of micturition and increasing thirst. The history is indefinite as to which of these appeared first. He consulted his physician, who asked him to measure his urine for twenty-four hours, when he found he voided seven quarts. Except for the large quantity, it was normal.

Physical Examination. - General examination negative, except for an old depressed scar at the site of a mastoid operation. Lungs negative.

Circulatory System: Blood pressure: systolic, 155; diastolic, 95; otherwise negative.

Nervous System: All reflexes were normal; no evidence of intracranial pressure, except that the spinal fluid during lumbar puncture was under great pressure.

5. Maranon, G.: Abstr., Endocrinology 5:86, 1921. 
CLINICAL LABORATORY REPORTS

Urine.-Clear, pale, acid reaction, no sediment, sp. gr., 1.002; no albumin; no sugar. Microscopic examination negative.

Blood.-Red blood cells, 4,864,000; leukocytes, 9,000; hemoglobin, 100 per cent. (Sahli). Differential count normal. Wassermann negative.

Spinal Fluid.-Clear; under great pressure; cell count, 9 per c. mm. all globulin tests negative. Wasserman negative.

Roentgenogram of Skull. - Shows no abnormality of the pituitary fossa, except that the fossa is shallow and the clinoid processes are indistinct. Sphenoidal sinus clear.

\section{METABOLISM STUDIES}

Since certain observations made are applicable to the study of more than one of the various problems which suggested themselves, and repetition of these observations was not practicable, they are recorded with comment only, but all are correlated under the general discussion.

GENERAL BLOOD CHEMISTRY

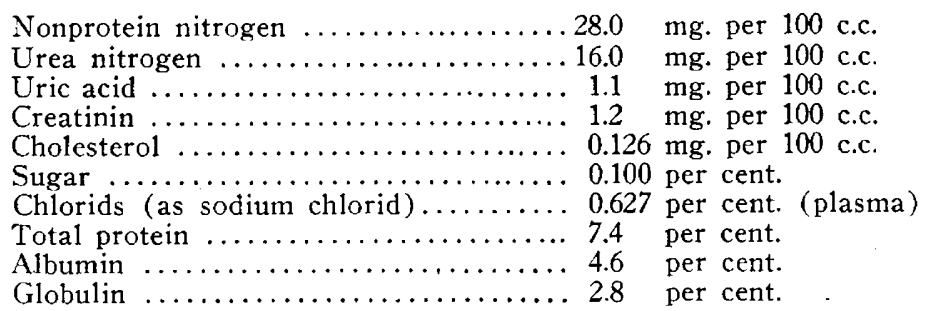

The only abnormal finding here is the hyperchloremia.

\section{ENDOCRINE STUDIES}

The close association of the function of the various endocrine organs has repeatedly been demonstrated. Since certain of these, e.g., suprarenal, thyroid and pituitary, have been shown to effect diuresis, these were studied.

\section{BASAL METABOLISM}

Apparatus used: Benedict respiration apparatus. ${ }^{e}$

Method.-The examinations were always made when the patient was in the postabsorptive state, and only a fter a preliminary rest period, ${ }^{7}$ when the pulse rate, blood pressure and respiration rate were determined. The average normal oxygen consumption per minute, per square meter of body surface was taken from the tables of calories given by Drs. Aub and DuBois ${ }^{8}$ using an average value of 4.83 calories per liter of oxygen, and an average normal respiratory quotient of 0.82 . Under normal average conditions, 1 c.c. oxygen consumed has a value for heat production of 0.29 calories for each square meter of body

6. Benedict, F. G.: A Portable Respiration Apparatus for Clinical Use, Boston M. \& S. J. 178:867, 1918.

7. Boothby, W. M., and Sandiford, I.: Technic of Basal Metabolic Rates Determinations, Philadelphia, W. B. Saunders Company, 1920.

8. Aub, J. C., and DuBois, E. F.: The Basal Metabolism of Old Men, Arch. Int. Med. 19:823 (May) 1917. 
surface. The body surface was calculated from the formula of DuBois and DuBois ${ }^{\circ} \mathrm{A}-\mathrm{W} 0.425 \times \mathrm{H} 0.725 \times 7.25$. After the normal basal values of the patient were found, the effect was noted after the administration of epinephrin chlorid, a pituitary extract and thyroxin.

During the period of this observation the blood pressure and pulse rate were taken every five minutes for two hours, and the basal metabolic rate was determined for a ten minute period at the end of $10,30,60,90$ and 120 minutes, respectively.

TABLE 1.-Epinephrin Curve

\begin{tabular}{|c|c|c|c|c|c|c|}
\hline & \multirow{4}{*}{$\begin{array}{c}\text { Pulse } \\
\text { per } \\
\text { Minute } \\
72\end{array}$} & & & \multirow{4}{*}{$\begin{array}{c}\text { Respira- } \\
\text { tions } \\
\text { per } \\
\text { Minute } \\
24\end{array}$} & \multicolumn{2}{|c|}{ Metabolic Rate } \\
\hline & & \multicolumn{2}{|c|}{ Blood Pressure } & & $\begin{array}{l}\text { C.c. Oxygen } \\
\text { per Min. per }\end{array}$ & $\begin{array}{l}\text { Percentage } \\
\text { Devia- }\end{array}$ \\
\hline & & Systolic & Diastolic & & Body Surface & Basal \\
\hline 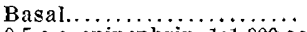 & & 150 & 96 & & 134.3 & .. \\
\hline \multicolumn{7}{|c|}{0.5 c.c. epinephrin, $1: 1,000$ solution } \\
\hline 10 minutes later......... & 76 & 152 & 96 & 24 & 147.6 & 11 \\
\hline 30 minutes later......... & 72 & 150 & 96 & 24 & 144.9 & 9 \\
\hline 60 minutes later.......... & 70 & 148 & 96 & 24 & 134.3 & 1 \\
\hline 90 minutes later........... & 61 & 150 & 96 & 24 & 135.6 & 2 \\
\hline 120 minutes later......... & 72 & 146 & 96 & 24 & 131.6 & 1 \\
\hline
\end{tabular}

The thyroxin was given after the epinephrin and pituitary extract tests were completed.

The normal findings under basal conditions do not justify the conclusion that there is no disturbance of the endocrine system, as it has been shown ${ }^{10}$ that the basal metabolism is the result of the sum total activities of the various glands. So long as one gland shows hyperfunction and another shows hypofunction to the same degree,

TABLE 2.-MetaBolic Rate

\begin{tabular}{|c|c|c|c|c|c|c|c|c|c|c|}
\hline \multirow{3}{*}{ • } & \multirow{2}{*}{\multicolumn{2}{|c|}{$\begin{array}{c}\text { Metabolic } \\
\text { Rate }\end{array}$}} & \multicolumn{4}{|c|}{ Blood Pressure } & \multirow{2}{*}{\multicolumn{2}{|c|}{ Puise }} & \multirow{2}{*}{\multicolumn{2}{|c|}{ Respiration }} \\
\hline & & & Sys & olic & Dias & tolic & & & & \\
\hline & $\overparen{\text { Basal }}$ & High & $\overparen{\text { Basal }}$ & $\overrightarrow{\text { High }}$ & Basal & High & Basal & High & Basal & High \\
\hline $1: 1,000 \ldots \ldots \ldots \ldots \ldots$ & $\cdot 1$ & 11 & 150 & 154 & 96 & 96 & 72 & 74 & 24 & 24 \\
\hline 1c.c.pituitary extract & 2 & 4 & 156 & 164 & 92 & 92 & 74 & 80 & 24 & 24 \\
\hline $\begin{array}{l}10 \mathrm{mg} \text {. thyroxin six } \\
\text { days previously.... }\end{array}$ & 2 & 18 & 148 & 160 & 92 & 86 & 70 & 88 & 24 & 28 \\
\hline
\end{tabular}

the basal metabolism may be normal. The remarkable subnormal response to epinephrin in this case, as compared with the average findings reported in normal individuals, ${ }^{11}$ suggests the possibility of

9. DuBois and DuBois, E. F.: A Formula to Estimate the Approximate Surface Area if Height and Weight Be Known, Arch. Int. Med. 17:863 (June) 1916.

10. Brock, S. R., and Kay, W. E.: A Study of Unusual Endocrine Disturbances, Arch. Int. Med. 27:1 (Jan.) 1921.

11. Sandiford, I.: The Effect of the Subcutaneous Injection of Adrenalin Chlorid on the Heat Production, Blood Pressure and Pulse Rate in Man, Am. J. Physiol. 51:407, 1920. 
hypofunction of the chromaffin system. That this may play a part in the polyuria is possible, since it has been suggested ${ }^{12}$ that the suprarenals act, in part, as a regulator of urinary excretion. To further investigate whether a hypofunction of the chromaffin system existed, the Csepai conjunctival, ${ }^{13}$ Goetsch subcutaneous epinephrin test, and Ascoli subepidermal epinephrin test ${ }^{14}$ were studied.

Csepai Conjunctizal Test: Normally three drops of 1:1000 epinephrin solution causes a slight or moderate blanching of the conjunctional sac persisting from ten to twenty minutes. In this case, the blanching was slight and persisted for six minutes. This test was regarded as negative.

The Goetsch test was negative (Table 3 ).

Ascoli Subepidermal Test: Normally, 0.5 c.c. of $1: 1,000$ epinephrin solution causes the appearance of a swelling which, after a few seconds, assumes a dark inklike color. The swelling becomes surrounded

TABLE 3.-Response to Goetsch Epinephrin Test (5 c.c. epinephrin $1: 1,000$ solution)

\begin{tabular}{|c|c|c|c|}
\hline \multirow[b]{3}{*}{ 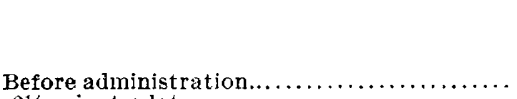 } & \multirow{3}{*}{ Pulse } & \multicolumn{2}{|c|}{ Blood Pressure } \\
\hline & & Systolic & Djastolic \\
\hline & & 152 & 88 \\
\hline 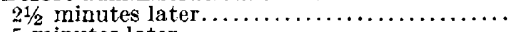 & 72 & & \\
\hline 5 minutes later $\ldots \ldots \ldots \ldots \ldots \ldots \ldots \ldots \ldots$ & 74 & 150 & 90 \\
\hline 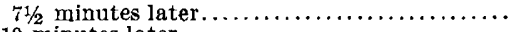 & 72 & & \\
\hline 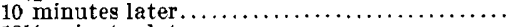 & 72 & 150 & 90 \\
\hline 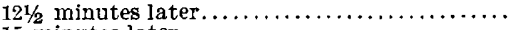 & 68 & & \\
\hline 15 minutes later $\ldots \ldots \ldots \ldots \ldots \ldots \ldots \ldots \ldots \ldots \ldots$ & 72 & 148 & 86 \\
\hline 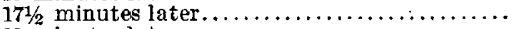 & 68 & & \\
\hline 20 minutes later $\ldots \ldots \ldots \ldots \ldots \ldots \ldots \ldots \ldots \ldots$ & 68 & 150 & 88 \\
\hline 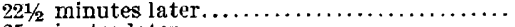 & 68 & & \\
\hline 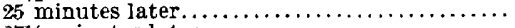 & 72 & 152 & 88 \\
\hline 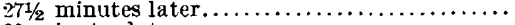 & 70 & & \\
\hline 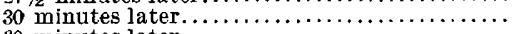 & 68 & 150 & 90 \\
\hline 60 minutes later.$\ldots \ldots \ldots \ldots \ldots \ldots \ldots \ldots \ldots \ldots \ldots$ & 72 & & \\
\hline 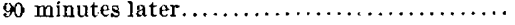 & 70 & 1.48 & 88 \\
\hline
\end{tabular}

by a pale halo of irregular projections, surrounded by a red zone. Normally, this reaction may be found, according to Ascoli, with dilutions even of $1: 200,000$.

In the case studied, with a 1:1,000 solution the blue-black central spot was present; there was slight blanching, but no red halo, and, therefore, this test was only slightly positive.

Ascoli pointed out that in the great majority of normal individuals the pathologic reactions to epinephrin and pituitary extract are dissociated and opposed. Since diabetes insipidus has been associated

12. McLeod, J. J. R.: The Endocrine Organs, Physiology and Biochemistry in Modern Medicine, Ed. 3, C. V. Mosby, St. Louis, p. 776, 1920.

13. Howard, C. P.: Functional Diagnosis of Polyglandular Disease, etc., Am. J. M. Sc. 158:834, 1919.

14. Ascoli, M., and Fagiuoli, A.: Pituitrin Test, Endocrinology 4:33, 1920. 
with pituitary disease, tests for hypofunction of this gland were studied, including the Ascoli pituitary extract test ${ }^{14}$ and that of Brock and Kay. ${ }^{10}$

Ascoli Test: Using the usual strength of obstetric pituitary extract as sold in the ampules, a reaction similar to that of a solution of epinephrin $1: 1,000$ is supposed to occur. This, contrary to expectations, did not occur, except as a slight suggestion of redness.

TABLE 4.-Results of Brock and Kay's Test

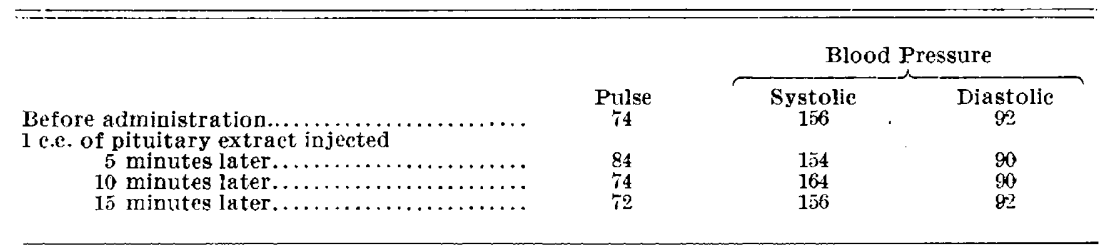

Although there was a slight rise in the systolic pressure, it was not marked enough, taking the personal equation of reading into consideration, to regard it as definitely positive.

Much clinical and experimental data tend to suggest that the pituitary body is concerned with carbohydrate metabolism. The finding of an increased sugar tolerance in acromegaly and pituitary tumors have been repeatedly reported. Keeton and Becht have shown that a hyperglycemia, associated with pituitary stimulation, is absent after transection of the spinal cord. Howard ${ }^{13}$ states that a diminished sugar tolerance in the presence of other symptoms, suggestive of disturbance of the pituitary body, justifies a diagnosis of increased activity of the pars intermedia.

TABle 5.-Sugar Tolerance Test

\begin{tabular}{|c|c|c|}
\hline 8 a. m. fasting $\ldots \ldots \ldots \ldots, \ldots, \ldots, \ldots, \ldots, \ldots, \ldots$, & Blood Sugar, per Cent. & $\underset{0}{\text { Urine Sugar }}$ \\
\hline 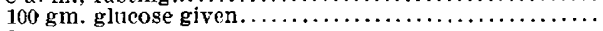 & & \\
\hline 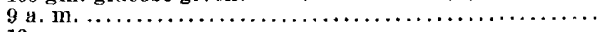 & 0.206 & + \\
\hline 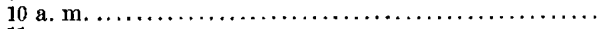 & 0.168 & + \\
\hline 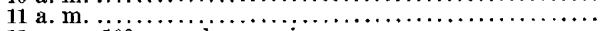 & 0.120 & 0 \\
\hline 12 a. m., 100 gm. glucose given & & \\
\hline 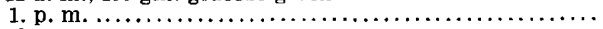 & 0.196 & + \\
\hline 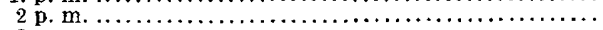 & 0.162 & + \\
\hline 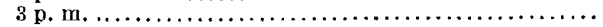 & 0.126 & 0 \\
\hline
\end{tabular}

Contradictory findings have recently been reported." Partial removal of one or both lobes of the pituitary body, or its total removal, did not appreciably modify the tolerance for carbohydrate, nor was it associated with the appearance of an alimentary glycosuria, and the injection of pituitary extract from the posterior lobe, anterior lobe or of the whole gland of the hypophysis did not sensibly modify-in the animals operated on-the tolerance for carbohydrate. Clinically, 
however, the association of diseases of this gland and disturbance of sugar metabolism is definite. For this reason, the carbohydrate metabolism was studied. The method employed was the determination of the blood sugar, after a fifteen hour fasting period. Then $100 \mathrm{gm}$. glucose in 250 c.c. water flavored with lemon juice was administered, and the degree of hyperglycemia and glycosuria was determined at one hour periods, until the original findings had returned. The method used in determining the blood sugar was that of Folin and $\mathrm{Wu}^{15}$

The blood sugar during the fasting period is rather high, with the method employed. Following the first administration of glucose, there is definite evidence of diminished tolerance, as shown by the glucosuria and suggestive evidence of delayed assimilation. The original concentration of the blood sugar was reached within the normal period, but the curve has a tendency to be rounded-not peaked. After the

TABLE 6.-Data on URINe for Twelve Hours

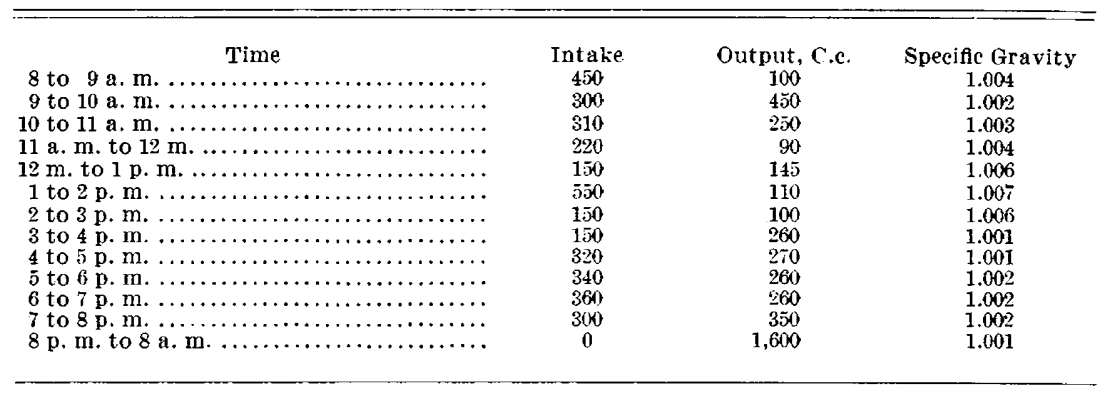

second administration of glucose, there was also a diminished tolerance, and practically to the same degree. This makes the test more positive, since normally an increased tolerance is expected after repeated injections. ${ }^{16}$

RÉSumÉ.-In the study of the basal metabolism of a case of diabetes insipidus a normal rate was found. There was no evidence of increased activity greater than would be expected with the dose of thyroxin administered. A diminished sugar tolerance was demonstrated, suggesting hyperfunction of the pituitary gland, and hypofunction of the suprarenals was suggested by subnormal response of the basal metabolic rate to epinephrin and negative Csepai, Goetsch and Ascoli tests. A balance, apparently, is struck between those two abnormal functions in keeping the basal metabolism unaltered.

15. Folin, O., and Wu Hsien: A System of Blood Analysis, Suppl. 1, J. Biol. Chem. 41:367, 1920.

16. Hamman, L., and Hirschman, I. I.: Studies on Blood Sugar, Bull. Johns Hopkins Hosp. 30:306, 1919. 


\section{DIETARY AND KIDNEY FUNCTION STUDIES}

As a preliminary observation, the patient was allowed the regular full hospital diet and as much water as he cared to take. The intake of fluids was measured and the time at which they were consumed was noted. The urine was collected every hour, and the volume and specific gravity were recorded.

It will be noted that although, on the whole, there is some relation between intake and output of fluids, the lack of a definite relation occurred during the hourly periods, from 8 to 9 a. $\mathrm{m}$. and fro 1 to 2 p. m, and again during the night when no fluid was taken. The persistent low specific gravity is marked. The total nitrogen for the day was $5.621 \mathrm{gm}$. and for the night $7.302 \mathrm{gm}$., which is apparently the total average excretion on a full hospital diet. This figure has frequently been noted during preliminary observations in mild diabetics, in whom there was not an increased metabolism.

TABLE 7.-Results of Mosenthal Renal Test Meal

\begin{tabular}{|c|c|c|c|c|c|c|}
\hline & \multicolumn{2}{|c|}{ Urine } & \multicolumn{2}{|c|}{ Sodium Chlorid } & \multicolumn{2}{|c|}{ Nitrogen } \\
\hline $\begin{array}{l}\text { Hour } \\
8 \text { to } 10 \text { a.m. } \\
10 \text { a. m. to } 12 \mathrm{~m} \text {. } \\
12 \text { m. to } 2 \mathrm{p} . \mathrm{m} \text {. } \\
2 \text { to } 4 \mathrm{p.m} \text {. } \\
4 \text { to } 6 \mathrm{p.m} \text {. } \\
6 \text { to } 8 \mathrm{p.m} \text {. } \\
8 \text { p. m. to } 8 \text { a.m. }\end{array}$ & $\begin{array}{r}\text { C.c. } \\
90 \\
100 \\
135 \\
1.0 \\
115 \\
95 \\
390\end{array}$ & $\begin{array}{c}\text { Specific } \\
\text { Gravity } \\
1.020 \\
1.016 \\
1.013 \\
1.014 \\
1.015 \\
1.019 \\
1.020\end{array}$ & $\begin{array}{l}\text { Gm. } \\
0.108 \\
0.160 \\
0.432 \\
0.060 \\
0.092 \\
0.152 \\
0.780\end{array}$ & $\begin{array}{c}\text { Per Cent. } \\
\text { Concentration } \\
0.120 \\
0.160 \\
0.320 \\
0.040 \\
0.080 \\
0.160 \\
0.200\end{array}$ & $\begin{array}{l}\text { Gm. } \\
0.921 \\
1.008 \\
1.285 \\
1.152 \\
1.255 \\
0.718 \\
5.460\end{array}$ & $\begin{array}{c}\text { Per Cent. } \\
\text { Concentration } \\
1.02 \\
1.00 \\
0.95 \\
0.76 \\
1.09 \\
0.75 \\
1.04\end{array}$ \\
\hline 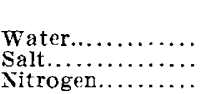 & $\begin{array}{l}\text { Bal } \\
\ldots \ldots \\
\cdots \cdots \\
\cdots \ldots\end{array}$ & $\begin{array}{l}\ldots \ldots \ldots \ldots \\
\cdots \cdots \cdots \cdots \\
\cdots \ldots \ldots\end{array}$ & $\begin{array}{l}\cdots \cdots \\
\cdots \cdots \\
\cdots \cdots\end{array}$ & $\begin{array}{r}\text { Intake } \\
1,760 \\
8.5 \\
1 \geq .6\end{array}$ & & $\begin{array}{c}\text { Output } \\
1,075 \\
1.184 \\
11.799\end{array}$ \\
\hline
\end{tabular}

The marked nocturnal polyuria and low concentration of nitrogen ( 0.456 per cent.) suggested impairment of kidney function, and seemed to support the theory that in diabetes insipidus, the kidneys are unable to excrete a concentrated urine. Therefore, the patient was placed on a Mosenthal renal test meal consisting of $12.6 \mathrm{gm}$. nitrogen, $8.5 \mathrm{gm}$. salt and 1,760 c.c. water, with the necessary restrictions. No food or fluids were allowed between meals. The meals were given at $8 \mathrm{a} . \mathrm{m}$., 12 noon and 5 p. m., and the urine was collected at two hour periods from 8 a. m. to 8 p. m. and one specimen from 8 p. m. to 8 a. m. the following day. The possibility of the previous habits and diet influencing the test was excluded by giving the Mosenthal renal test for two days previous to the actual test.

The balance shows a slight water retention and more marked chlorid retention, and a normal nitrogen balance (allowing 10 per cent. excretion by the feces). The night urine is normal in amount and in concentration of nitrogen, but low in salt. The two hour specimens 
show a normal concentration of nitrogen, but are low in salt. With the exception of the salt metabolism, the findings are normal. A striking feature is the ability of the kidney to excrete a urine of higher specific gravity on a restricted fluid diet than on an unrestricted one, and yet in the preliminary observations, there seemed to be no definite relation between the intake and output of fluids.

Since the renal test meal seemed to indicate that the metabolism of salt and water was at fault, observations were made with special reference to these. The problem was whether the kidneys were unable to concentrate salt or whether there were certain physicochemical changes in the tissues which removed the salt from the blood, and the salt did not reach a high enough concentration (threshold) to be excreted. That is a study was made of the relation between the concentration of the chlorid in the blood and its rate of excretion as described by McLean. ${ }^{17}$

The plasma chlorides were determined by the method of Whitehorn. ${ }^{18}$ The normal threshold was accepted as 5.62 gm. per liter.

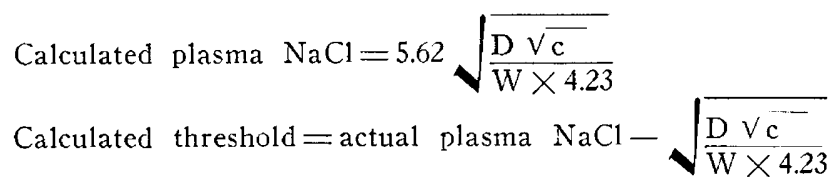

Where D-gm. per 24 hours.

Where C-gm. per liter.

Where $\mathrm{W}-$ weight in kilograms.

\begin{tabular}{|c|c|c|c|}
\hline \multirow{3}{*}{ 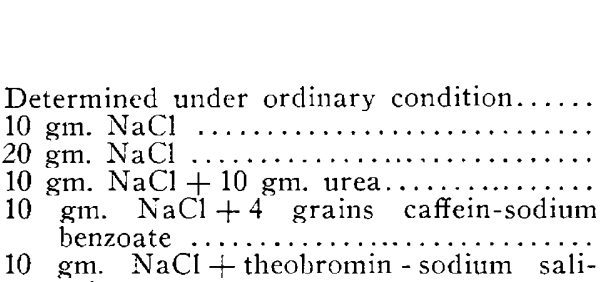 } & \multicolumn{3}{|c|}{ Plasma $\mathrm{NaCl} \underbrace{(\mathrm{gm} .}$ per liter) } \\
\hline & $\begin{array}{l}\text { Actual } \\
6.281 \\
6.290 \\
6.273 \\
6.286\end{array}$ & $\begin{array}{c}\text { Calculated } \\
5.641 \\
5.683 \\
6.002 \\
6.001\end{array}$ & $\begin{array}{c}\text { Threshold } \\
6.260 \\
6.227 \\
5.891 \\
5.905\end{array}$ \\
\hline & 6.286 & 5.679 & 6.227 \\
\hline 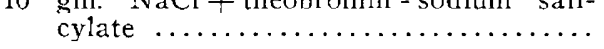 & 6.261 & 5.682 & 6.201 \\
\hline
\end{tabular}

The collection of specimens was followed as described by McLean. ${ }^{19}$

RÉsumé.--Judging from the normal values obtained by this method, there was a persistent hyperchloremia and a persistent high threshold. The administration of sodium chlorid stimulated the kidney to activity by lowering the threshold, and this effect was greater with the increased dose of sodium chlorid. The administration of urea, together with the small dose of sodium chlorid, did have some effect in lowering the

17. McLean, F. C.: The Numerical Laws Governing the Rate of Excretion of Urea and Chlorids in Man, J. Exper. M. 22:212, 1915.

18. Whitehorn, J. C.: A System of Blood Analysis, Suppl. II, J. Biol. Chem. 45: 449, 1921 . 
threshold, but not to the same degree as the administration of more salt. The diuretics, caffein and theobromin, had no appreciable effect. The ability of the kidney to excrete nitrogen readily, as shown by the renal test meal, was corroborated by testing the effect on the blood and urine of the administration of urea.

The renal meal was repeated, but $10 \mathrm{gm}$. urea were given by mouth at breakfast.

TABle 8.-Result of Second Renal Test Mfal

\begin{tabular}{|c|c|c|c|c|c|c|}
\hline \multirow{3}{*}{ 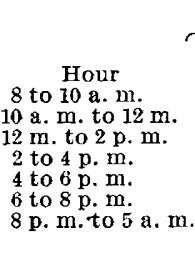 } & \multicolumn{2}{|c|}{ Urine } & \multicolumn{2}{|c|}{ Sodium Chlorid } & \multicolumn{2}{|c|}{ Nitrogen } \\
\hline & $\begin{array}{l}\text { C.c. } \\
190 \\
215 \\
165 \\
160 \\
100 \\
90 \\
320\end{array}$ & $\begin{array}{l}\text { Speeific } \\
\text { Gravity } \\
1.014 \\
1.012 \\
1.014 \\
1.015 \\
1.017 \\
1.019 \\
1.021\end{array}$ & $\begin{array}{l}\text { Gm. } \\
0.760 \\
0.860 \\
0.528 \\
0.896 \\
0.320 \\
0.216 \\
0.512\end{array}$ & $\begin{array}{c}\text { Per Cent. } \\
\text { Concentration } \\
0.400 \\
0.400 \\
0.320 \\
0.540 \\
0.320 \\
0.240 \\
0.160\end{array}$ & $\begin{array}{l}\text { Gm. } \\
2.390 \\
1.806 \\
1.755 \\
1.747 \\
1.232 \\
1.285 \\
5.286\end{array}$ & $\begin{array}{c}\text { Per Cent. } \\
\text { Concentration } \\
1.25 \\
0.84 \\
1.06 \\
1.09 \\
1.23 \\
1.42 \\
1.65\end{array}$ \\
\hline & 1,240 & & 4.092 & & 15.501 & \\
\hline
\end{tabular}

The balance shows that following the administration by mouth of urea there was a lessened tendency to retain salt and water and the nitrogen excretion was normal (allowing 10 per cent. excretion by stools and urea $=2.14 \times$ Urea $\mathrm{N}$ ).

The ability of the kidney to excrete nitrogen is well shown in Table 9. Although sufficient urea was given to raise the blood urea nitrogen to about $200 \mathrm{mg}$. per 100 c.c. (accepting 5 liters of blood as the average normal volume), the concentration of the blood urea nitrogen remained remarkedly constant.

TABLE 9.-Blood UREA

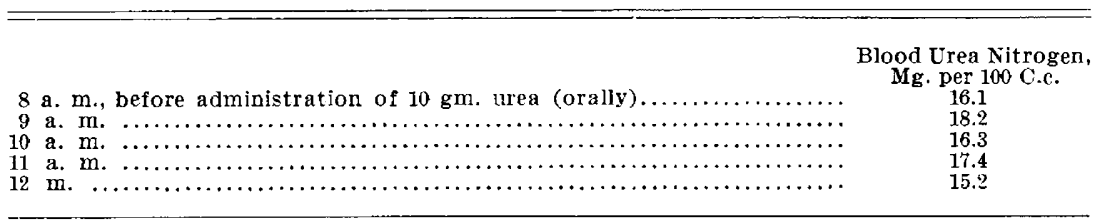

RÉSumÉ.-From these findings the conclusion is justified that there is an inability on the part of the kidney to excrete chlorids properly. That the kidney is unable to concentrate all solids is not proven since its ability to concentrate nitrogen is remarkedly good. The hyperchloremia, as found during the preliminary observations of this patient, is probably compensatory in nature, and favors excretion of sodium chlorid and is not a true retention. Clinically, there was no evidence of increase in weight, edema, etc. Since both a renal and hypophyseal factor are suggested in the case, observations were made on the effect of the administration of pituitary extract on the renal function. 
The renal meal was then repeated, and 1 c.c. of a pituitary extract was administered hypodermically at the $8 \mathrm{a} . \mathrm{m} ., 12 \mathrm{~m}$. and $5 \mathrm{p} . \mathrm{m}$. meals.

TABle 9.-Rresclt of Administration of Pituitary Extract

\begin{tabular}{|c|c|c|c|c|}
\hline \multirow{3}{*}{ Hour } & \multirow[b]{2}{*}{ C.c. } & \multirow{3}{*}{$\begin{array}{c}\text { Speciflc } \\
\text { Gravity } \\
1.024\end{array}$} & \multicolumn{2}{|c|}{ Sodium Chlorid } \\
\hline & & & Gm. & Per Cent. \\
\hline & 30 & & 0.220 & 0.31 \\
\hline $10 \mathrm{a} . \mathrm{m}$. to $12 \mathrm{~m} . \ldots \ldots \ldots \ldots \ldots \ldots \ldots$ & 130 & $1.01 \%$ & 0.410 & 0.31 \\
\hline $12 \mathrm{~m}$. to $2 \mathrm{p} . \mathrm{m} . \ldots \ldots \ldots \ldots \ldots \ldots \ldots$ & 70 & 1.022 & 0.126 & 0.18 \\
\hline 2 to 4 p.m. & 150 & 1.020 & 0.510 & 0.34 \\
\hline 4 to $6 \mathrm{p}, \mathrm{m}, \ldots \ldots \ldots \ldots \ldots \ldots \ldots \ldots$ & 130 & 1.026 & 0.426 & 0.32 \\
\hline 6 to 8 p.m. & 100 & 1.020 & 0.316 & 0.316 \\
\hline \multirow[t]{2}{*}{ 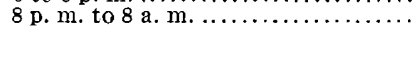 } & 300 & 1.022 & 3.100 & 1.03 \\
\hline & 950 & & 5.108 & \\
\hline
\end{tabular}

The injection of the pituitary extract was followed by a diminished diuresis, a retention of water and an increase in the salt excretion and concentration. That the concentration of salt is due to increased kidney activity and not only to retention of water is suggested by the greater excretion of salt and the analysis of the blood following the injection.

TABLE 10.-Sonium ChLoRid in BLood

\begin{tabular}{lcc}
\hline Actual, Gm. per Liter & Calculated, Gm. per Liter & Threshold, Gm. per Liter \\
$\mathbf{5 . 9 8 9}$ & \\
\hline
\end{tabular}

It will be seen (Table 10) that the hyperchloremia has diminished, but in spite of this, excretion takes place at a lower threshold.

The effect of the pituitary extract soon wore off as shown in Table 11.

TABLE 11.-Intakf and Ourput of Fluid Two Days Later

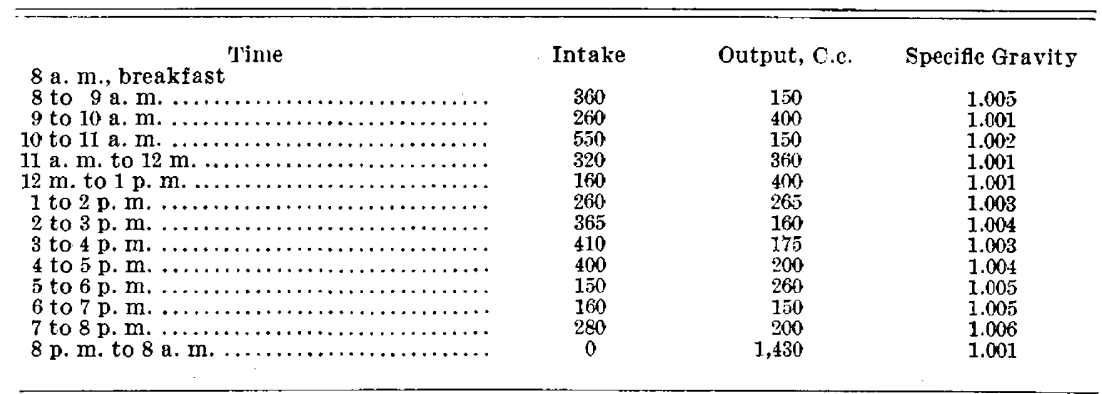

RÉSUMÉ.-In the case of diabetes insipidus studied, no single specific lesion has been found to account for the polyuria.

Functional analysis of the endocrine system shows hyperfunction oi the pituitary body and hypofunction of the suprarenals. A balance is struck between these two abnormal endocrine functions as shown 
by the normal basal metabolism. Although the polyuria disappears on a restricted fluid intake, there is no evidence that the polyuria is due to a primary polydipsia. The kidney function is normal in every respect, except in its ability to concentrate salt. That the condition is due to physicochemical processes removing the salts from the blood and thereby not allowing a normal threshold to exist is not proven. The hyperchloremia found is apparently compensatory, aiding the excretion of salt and is not a true retention since there is no clinical evidence of salt retention. The administration of pituitary extract definitely caused a diminution of the polyuria and an increased rate of flow and an increased concentration of salt in the urine.

\section{CONCLUSIONS}

In a case of diabetes insipidus studied there is no one specific cause for the polyuria. An endocrine and a renal factor were found. Since the administration of pituitary extract improved not only the concentration but also the rate of excretion, it is suggested that the theory advanced that diabetes insipidus is produced by a lack of some internal secretion which normally regulates and moderates diuresis by acting on the renal cells holds in this case. 